\title{
Pengabdian Peningkatan Keterampilan Menyusun Penelitian Tindakan Kelas (PTK) bagi Guru-Guru di Aceh Timur
}

\author{
Jamali $^{1}$, Muhammad Jamil ${ }^{2 *}$, Teuku Muana Refi ${ }^{3}$, Erni Wiriani ${ }^{4}$, Abdul Aziz $^{5}$ \\ 1,2,3,4 Program Studi Keuangan dan Perbankan, Fakultas Ekonomi, Akademi Keuangan Perbankan \\ Nusantara, Jl. Medan-Banda Aceh, Kabupaten Aceh Timur, Indonesia \\ Corresponding Email: muhammadjamil@akubanknusantara.ac.id ${ }^{2}$.
}

\section{Article History:}

Received: May 17th 2020

Revised: Dec 12th 2020

Accepted: Mar 20th 2021

Keywords: Devotion; Skills Improvement; Classroom Action Research; Teacher; East Aceh.
Abstract: The purpose of this activity is to train teachers in East Aceh District so that they are able to understand why it is important to implement PTK and teachers can compile PTK reports using learning models. The method of implementing community service activities consists of classical and discussion which includes several stages, namely; 1) submission of systematic material for proposal writing, 2) material regarding, 3) technical implementation of research, 4) clinical preparation of PTK, 5) assistance for research implementation and 6) preparation of final research reports. Based on the results of the activity it can be seen; 1) PTK is very important for teachers to understand as professional development of teachers through three things, namely; research, write and develop the profession in a sustainable manner and include learning models that can affect student learning outcomes, 2) The implementation of training and mentoring for teachers in East Aceh District can have a direct impact on increasing knowledge about the preparation of PTK by using models learning, has provided technical knowledge for teachers in order to compile PTK reports, 3) Local government response is needed, especially the Education Office in carrying out similar activities so that participants who take part in these activities are fulfilled seeing that the number of teachers in East Aceh Regency is high, 4) partnership and cooperation between the Indonesian Academy of Banking Finance, East Aceh Regency and SDN East Aceh Regency. 


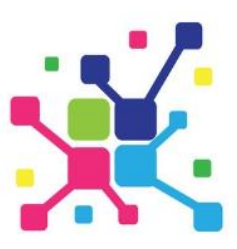

\section{Pendahuluan}

Diberlakukannya Undang-undang RI Nomor 14 Tahun 2005 tentang Guru dan Dosen, merupakan bukti pengakuan terhadap profesionalitas pekerjaan guru dan dosen [1]. Terlebih lagi di dalam pasal 14 dan 15 Undang-undang tersebut dinyatakan bahwa guru berhak memperoleh penghasilan di atas kebutuhan hidup minimum dan jaminan kesejahteraan sosial, meliputi gaji pokok, tunjangan yang melekat pada gaji, serta penghasilan lain berupa tunjangan profesi, tunjangan fungsional, tunjangan khusus, dan maslahat tambahan yang terkait dengan tugasnya sebagai guru yang ditetapkan dengan prinsip penghargaan atas dasar prestasi $[2,3]$.

Dewasa ini, dengan adanya sertifikasi guru para pendidik dituntut untuk mampu meneliti [4,5]. Tuntutan agar guru mampu meneliti semakin gencar dilakukan oleh pemerintah [6,7]. Hal itu dibuktikan dari laporan portofolio guru yang mensyaratkan melampirkan karya tulisnya dalam sertifikasi guru dalam jabatan karena hal itulah maka guru-guru di sekolah harus dapat meneliti di kelasnya sendiri dengan tujuan memperbaiki kualitas pembelajarannya melalui Penelitian Tindakan Kelas (PTK) [8,9]. PTK merupakan implementasi dari kreativitas dan kekritisan seorang guru terhadap apa yang sehari-hari diamati [10], dan dialaminya sehubungan dengan profesinya untuk menghasilkan kualitas pembelajaran yang lebih baik sehingga mencapai hasil belajar yang optimal $[11,12]$.

Penelitian Tindakan Kelas adalah penelitian praktis yang dimaksudkan untuk memperbaiki pembelajaran di kelas [13]. Penelitian ini merupakan salah satu upaya guru atau praktisi dalam bentuk berbagai kegiatan yang dilakukan untuk memperbaiki dan atau meningkatkan mutu pembelajaran di kelas [14, 15]. Guru juga dituntut dapat melakukan penelitian di kelasnya sendiri untuk melihat bagaimana peningkatan hasil belajar siswa dengan menggunakan model pembelajaran yang bervariasi [16, 17]. Pelatihan dan pendampingan ini dilakukan sebagai salah satu pengabdian kepada masyarakat yang berkaitan dengan perkembangannya pendidikan [18]. Guru selalu merasa tidak mampu untuk membuat sebuah karya tulis berupa PTK karena guru masih cenderung menggunakan model pembelajaran yang biasa saja, dan kurang pahamnya guru terhadap teknologi yang semakin berkembang $[16,18]$.

Namun, berdasarkan pengamatan tim pengabdi masih banyak guru-guru yang belum mengenal dan belum melakukan PTK sama sekali di kelasnya. Sehingga tujuan dari worshop ini adalah mengajak atau memotivasi guru yang masih enggan mengadakan penelitian karena berbagai alasan untuk dapat mengembangkan potensi siswa yang ada di kelasnya. Dengan mengetahui potensi siswa, guru menjadi semakin dekat dengan para siswanya, dan terjadilah proses interaktif di antara guru dan siswa. Pengabdian ini juga mengajak guru untuk melangkah kepada berbagai catatan yang setelah diolah dapat mewujud menjadi suatu penelitian yang berkualitas. Melaksanakan penelitian tentang apa yang sehari-hari dilakukan oleh seorang guru yang akhirnya dapat menghasilkan 
suatu karya yang disebut PTK. Hal itu dapat terjadi apabila suatu urutan umum prosedur, yaitu bermula dari identifikasi masalah penelitian yang dihadapi sampai dengan laporan hasil akhirnya dicatat. Jadi, amat penting suatu prosedur ini dipahami dan ditaati oleh guru yang meneliti.

Berdasarkan hal tersebut, maka tim pengabdian Akademi Keuangan Perbankan Nusantara Kabupaten Aceh Timur yang berpengalaman dalam penelitian untuk melakukan suatu kegiatan Pengabdian Peningkatan Keterampilan Menyusun Penelitian Tindakan Kelas (PTK) bagi Guru-Guru di Aceh Timur untuk aktif menulis, meneliti dan menuliskan laporan penelitiannya sehingga dapat meningkatkan kualitas pembelajarannya di kelas. Disamping materi PTK, juga disuguhkan materi pendukung yaitu menyusun laporan PTK dengan menggunakan model-model pembelajaran.

Tujuan kegiatan ini adalah untuk melatih menggunakan guru-guru di Kabupaten Aceh Timur sehingga mampu memahami mengapa penting melaksanakan PTK dan guru dapat menyusun laporan PTK dengan menggunakan model-model pembelajaran. Manfaat yang diharapkan dari pelatihan ini adalah guru yang ada di tingkat SD mampu memahami mengapa penting melaksanakan PTK dan guru dapat Menyusun laporan PTK dengan menggunakan model-model pembelajaran.

\section{Metode}

a. Metode Pelaksanaan Kegiatan

Metode pelaksanaan kegiatan pengabdian terdiri dari klasikal dan diskusi yang meliputi beberapa tahapan yaitu; 1) penyampaian materi sistematika penulisan proposal, 2) materi mengenai, 3) teknis pelaksanaan penelitian, 4) klinik penyusunan PTK, 5) pendampingan pelaksanaan penelitian, dan 6) penyusunan laporan akhir penelitian.

b. Waktu Efektif Pelaksanaan Kegiatan

Kegiatan Pelaksanaan Pengabdian Kepada Masyarakat ini dilakukan pada awal Oktober 2020 sampai dengan Desember 2020.

c. Tempat Kegiatan

Lokasi pengabdian ini dilaksanakan pada ruang Akademi Keuangan Perbankan Nusantara Kabupaten Aceh Timur. 


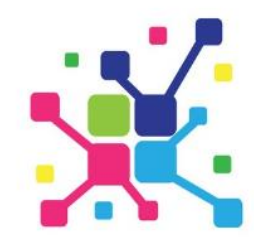

A J A D

Jurnal Pengabdian kepada Masyarakat

Vol. 1, No. 1, May, 2021, pp. 1-8

DOI : https://doi.org/10.35870/ajad.v1i1.2

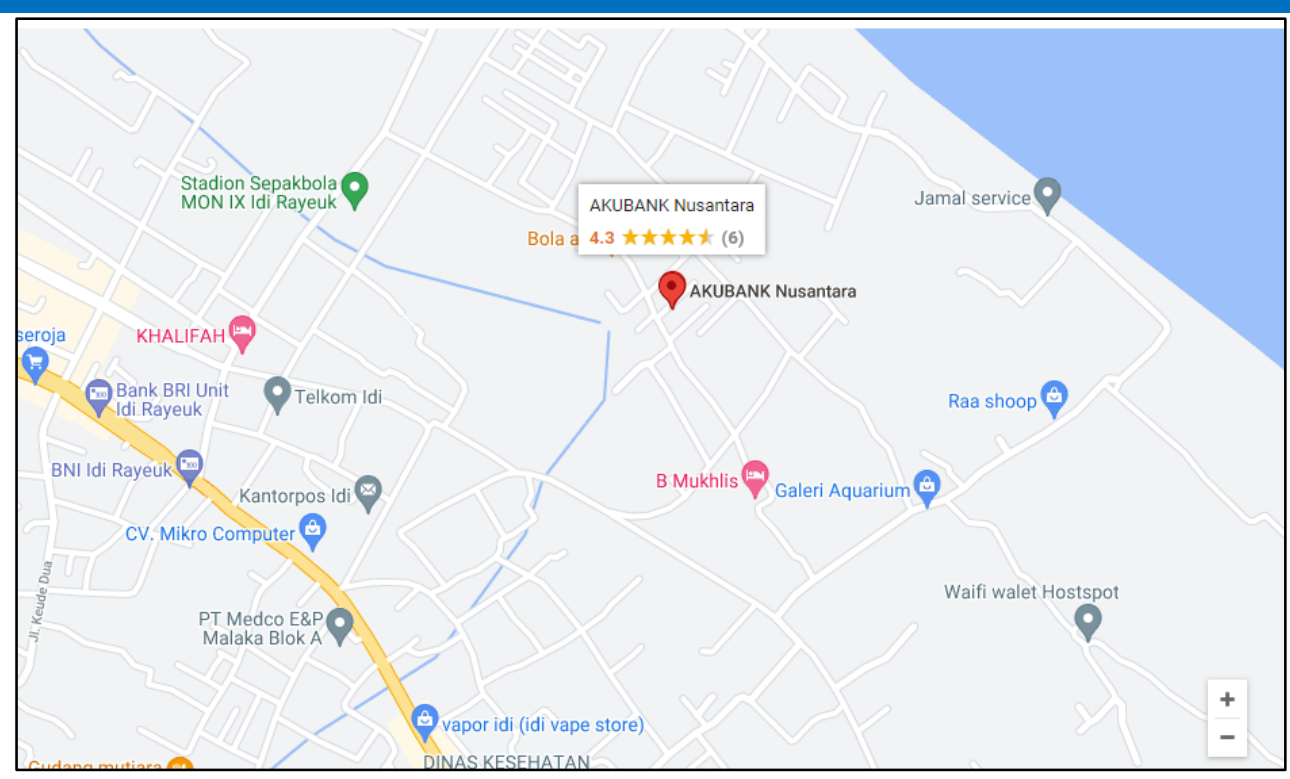

Gambar 1. Map Lokasi Kegiatan

\section{Hasil}

Bentuk langkah-langkah kongkrit yang dilaksanakan dalam pelatihan ini sehingga pelatihan ini dapat berhasil dilaksanakan adalah sebagai berikut :

1. Peserta pelatihan diberikan materi tentang panduan membuat penelitian tindakan kelas (PTK).

2. Peserta diberikan kesempatan untuk mendiskusikan materi yang telah diberikan. Kesempatan tanya jawab diberikan untuk memperjelas hal-hal yang masih menjadi keraguan.

3. Peserta berlatih untuk membuat penelitian tindakan kelas (PTK).

4. Peserta melakukan penelitian dengan menggunakan siswanya masing-masing untuk melihat peningkatan hasil belajar siswa dengan menggunakan model pembelajaran yang bervariasi.

5. Peserta melakukan presentasi PTK

6. Hasil karya peserta dikumpulkan dan dianalisis untuk diberikan masukan dan perbaikan lebih lanjut. 


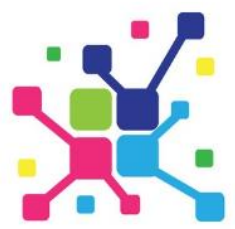

A J A D

Jurnal Pengabdian kepada Masyarakat

Vol. 1, No. 1, May, 2021, pp. 1-8 DOI : https://doi.org/10.35870/ajad.v1i1.2

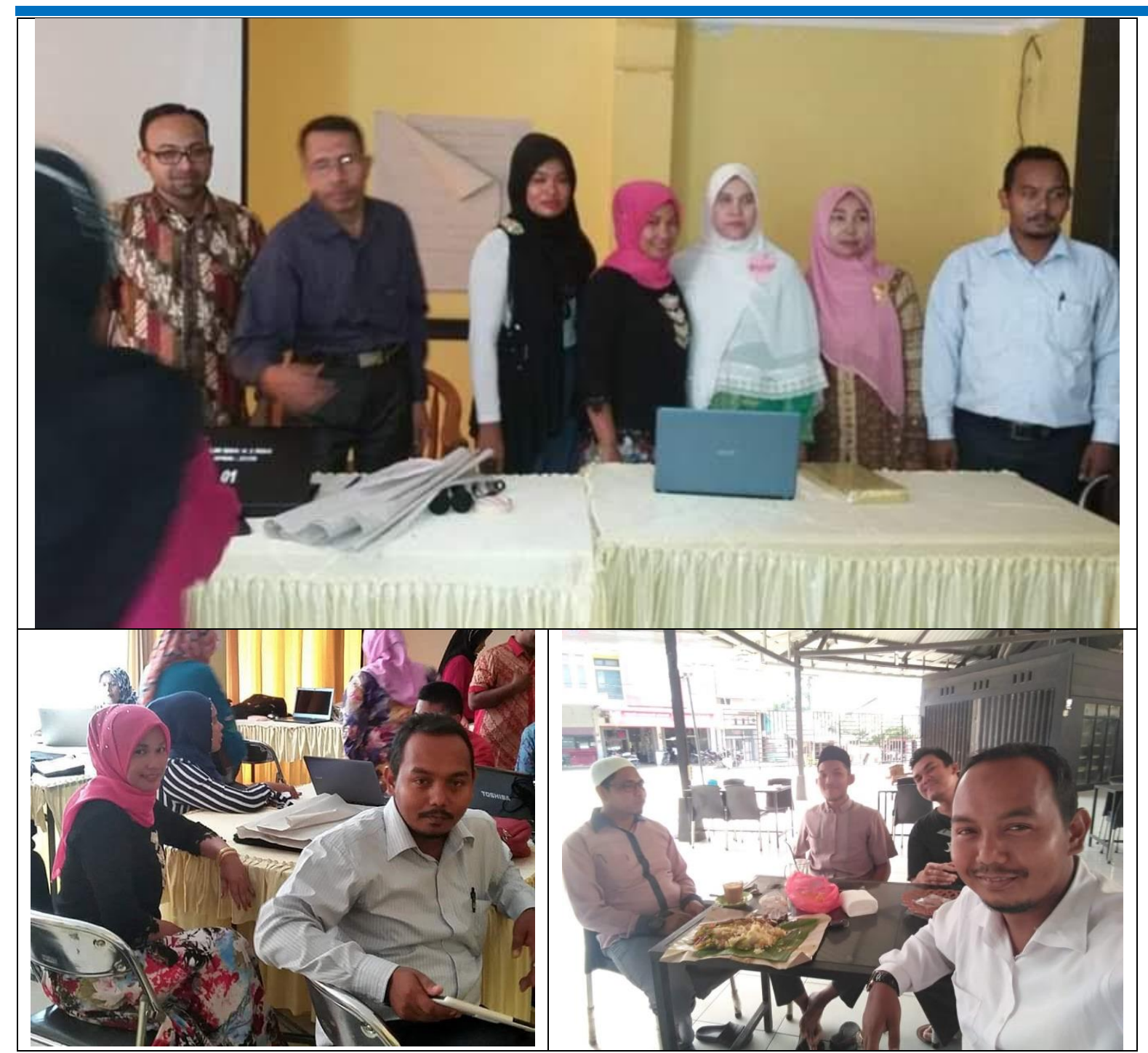

Gambar 2. Hasil Kegiatan

Berdasarkan pengamatan dan evaluasi yang dilakukan selama pelatihan, dapat dilaporkan bahwa kegiatan PPM yang bertempat di ruang Akademi Keuangan Perbankan Nusantara Kabupaten Aceh Timur telah berhasil dilaksanakan dengan materi pelatihan Peningkatan Keterampilan Menyusun Penelitian Tindakan Kelas (PTK) bagi Guru-Guru di Aceh Timur yang dilaksanakan selama 3 Bulan (22 Hari).

a. Faktor Pendukung

Faktor pendukung dalam melaksanakan program pelatihan ini adalah adanya dukungan dana dari pihak Akademi Keuangan Perbankan Nusantara Kabupaten Aceh Timur serta sudah adanya ruang pertemuan yang sudah dilengkapi dengan fasilitas seperti infocus dan peralatan pendukung lainnya.

b. Faktor Penghambat

Secara prinsip tidak ditemukan faktor penghambat yang berarti. Namun yang menjadi sedikit hambatan adalah jadwal pelaksanaan yang harus menyesuaikan 
dengan kesibukan dari tim PPM (dosen Akademi Keuangan Perbankan Nusantara) dan kesibukan dari peserta, serta lokasi kegiatan dengan tempat rumah peserta terkesan tidak strategis. Dan ditambah lagi Pademi COVID-19 yang mengakibatkan sebagian tidak ingin menghadiri kegiatan tersebut. Hal tersebut mengakibatkan motivasi peserta dalam mengikuti pelatihan hanya 30\% dari guru yang diundang untuk mengikuti pelatihan ini.

c. Evaluasi

Sesi materi Sistematika Penyusunan Penelitian Tindakan Kelas (PTK) dan materi pelaksanaannya berlangsung sangat baik. Minggu pertama, Peserta sangat antusias mengikuti kegiatan sampai akhir. Indikator lainnya adalah suasana terlihat hidup dengan adanya sesi anya jawab dan diskusi di antara pelaksana PKM dengan guruguru yang mengikuti kegiatan ini. Klinik penyusunan PTK berjalan sangat baik karena terjadi diskusi antar anggota kelompok, kelompok satu dengan kelompok lain dan juga pengabdi sebagai fasilitator. Sesi klinik diakhiri dengan presentasi draft PTK yang telah disusun oleh masing-masing kelompok. Sesi ini berjalan lancar dan sesuai target yaitu semua kelompok membuat draft judul dan latar belakang masalah PTK untuk dipresentasikan. Selanjutnya setelah mempresentasikan draft PTK, masingmasing kelompok merevisi sesuai masukan dari kelompok lain dan fasilitator. Model pendampingan untuk penyempurnaan draft PTK selanjutnya melalui email kurang lebih memakan waktu sekitar dua minggu.

PTK yang sudah layak, disarankan melanjutkan ke tahap berikutnya yaitu pelaksanaan penelitian tindakan kelas. Kriteria PTK yang layak adalah sudah memenuhi standar PTK pada umumnya yaitu memiliki latar belakang yang kuat, rumusan masalah yang tajam, tujuan yang jelas, landasan teori yang sesuai dan tahapan kegiatan penelitian yang semestinya. Berdasarkan data guru yang diperoleh dari Data Pokok Pendidikan Direktorat Jenderal Pendidikan Anak Usia Dini, Pendidikan Dasar dan Pendidikan Menengah Kementerian Pendidikan dan Kebudayaan, berdasarkan data Semester Ganjil 2020/2021 terdapat 7.518 Guru baik PNS maupun Non PNS yang tersebar pada 24 Kecamatan di Kabupaten Aceh Timur, terdapat Guru yang berjenis kelami Laki-Laki sebanyak 1.483 dan Perempuan sebanyak 6.100. Dari target 100 orang guru yang diberi pendampingan, 30 orang guru yang hadir dalam pelatihan dan pendampingan penyusunan PTK di UPT Sekolah Dasar. Data itu diperoleh dari daftar hadir guru masingmasing sekolah yang dibuat oleh tim pengabdian masyarakat. Adapun ruang lingkup utama dari kegiatan pengabdian kepada masyarakat ini adalah untuk meningkatkan pengetahuan dan wawasan guru dalam pelatihan Peningkatan Keterampilan Menyusun Penelitian Tindakan Kelas (PTK) bagi Guru-Guru di Aceh Timur. 


\section{Kesimpulan}

1. PTK sangat penting dipahami bagi Guru sebagai pengembangan keprofesian guru melalui tiga hal yaitu; meneliti, menulis dan mengembangkan keprofesian secara berkelanjutan serta menyertakan model-model pembelajaran yang dapat mempengaruhi hasil belajar siswa.

2. Penyelenggaraan pelatihan dan pendampingan bagi guru-guru di Kabupaten Aceh Timur dapat memberikan dampak langsung untuk menambah pengetahuan tentang penyusunan PTK dengan menggunakan model-model pembelajaran, telah memberikan pengetahuan teknis bagi para guru dalam rangka menyusun laporan PTK.

3. Diperlukan tanggapan Pemerintah Daerah khususnya Dinas Pendidikan dalam menyelenggarakan kegiatan serupa sehingga terpenuhi peserta yang mengikuti kegiatan tersebut melihat jumlah Guru-guru di Kabupaten Aceh Timur tergolong tinggi.

4. Terjalin kemitraan dan kerjasama antara pihak Akademi Keuangan Perbankan Nusantara Kabupaten Aceh Timur dan SDN Kabupaten Aceh Timur.

\section{Daftar Referensi}

[1] Radiansyah, R., Jannah, F. and Sari, R., 2021. Workshop Pembuatan Penelitian Tindakan Kelas bagi Guru Sekolah Dasar di Kecamatan Barabai Kabupaten Hulu Sungai Tengah.PengabdianMu: Jurnal Ilmiah Pengabdian kepada Masyarakat, 6(2), pp.170-174.

[2] Natsir, N.F., 2007. Peningkatan Kualitas Guru dalam Perspektif Pendidikan Islam. Educationist, 1(1), pp.20-27.

[3] Aqib, Z. and Chotibuddin, M., 2018. Teori dan Aplikasi Penelitian Tindakan Kelas:(PTK). Deepublish.

[4] Iqbal, T., Mukhtar, M., Munawir, M., Syarifuddin, S. and Al-Bahri, F.P., 2020. IbM Sosialisasi Model Permainan untuk Pengembangan Sosial Emosional Anak. Jurnal Pengabdian Nasional (JPN) Indonesia, 1(1), pp.23-29.

[5] Takda, A., Tahang, L., Sukariasih, L. and Sahara, L., 2021. PELATIHAN PEMBUATAN VIDEO PEMBELAJARAN BERBASIS POWTOON SEBAGAI ALTERNATIF MEDIA PEMBELAJARAN PADA GURU SMP-TQ MU'ADZ BIN JABAL KENDARI. Jurnal Pengabdian Masyarakat Nusantara (JPMN), 1(1), pp.8-17.

[6] Inayati, N.L., Kasanah, U.N. and Khotimah, K., 2021. PENDAMPINGAN METODE MUSĀBAQAH BIṬĀQAH MUKHTALIṬUL KALIMAH DALAM PEMBELAJARAN 
BAHASA ARAB DI PONDOK PESANTREN DARUSY SYAHADAH BOYOLALI. Jurnal Pengabdian Masyarakat Nusantara (JPMN), 1(1), pp.18-30.

[7] Murtiningsih, M., 2020. Penyuluhan Kesehatan Pola Hidup Sehat Secara Daring menggunakan Zoom dan Youtube Sebagai Media Ajar pada Masa Pandemi COVID-19. Jurnal Pengabdian Nasional (JPN) Indonesia, 1(2), pp.37-40.

[8] Pramulia, P., Rachmadtullah, R., Fanani, A., Kusmaharti, D. and Susiloningsih, W., 2020. PELAPORAN CLASSROOM BASED ACTION RESEARCH BAGI GURU SEKOLAH DASAR DI KECAMATAN SIDAYU. J-ADIMAS (Jurnal Pengabdian kepada Masyarakat), 8(1), pp.31-36.

[9] Asrin, A., Karta, I.W., Waluyo, U. and Muntari, M., 2020. Workshop Penelitian Tindakan Kelas (PTK) Inovatif Bagi Guru SMAN 1 Kopang Lombok Tengah. Jurnal Pengabdian Magister Pendidikan IPA, 3(1).

[10] Anggraeni, A.D. and Nurani, S., 2018. Penyusunan Proposal Penelitian Tindakan Kelas (PTK) pada Guru-Guru Sekolah Yayasan Kholifah Masa Depan Depok. Jurnal PkM Pengabdian kepada Masyarakat, 1(03), pp.199-204.

[11] Trisnawati, A. and Setiawan, M.A., 2019, March. PELATIHAN PENULISAN KARYA TULIS ILMIAH BAGI GURU SMK AL-INABAH PONOROGO. In Prosiding Seminar Nasional Hasil Penelitian LPPM Universitas PGRI Madiun (pp. 447-451).

[12] Ahmad, L., Sufyan, S. and Ahmad, A., 2020. Pelatihan Penggunaan Software Content Admission Sebagai Implementasi dari Konsep Complement Online Learning pada AMIK Indonesia. Jurnal Pengabdian Nasional (JPN) Indonesia, 1(2), pp.41-46.

[13] Hanifah, N., 2014. Memahami penelitian tindakan kelas: teori dan aplikasinya. UPI Press.

[14] Wibawa, B., 2003. Penelitian Tindakan Kelas. Jakarta: Dirjen Dikdasmen, pp.2721-2572.

[15] Subali, B. and Guru, S.M.A.N., 2008. Penelitian Tindakan Kelas. Makalah disajikan pada Kegiatan Latihan dan Bimbingan Penelitian Tindakan Kelas bagi Guru SMAN, 1 .

[16] Guru, M.P.L.P., 2011. Penelitian Tindakan Kelas. Surabaya. UNesa Modul Pendidikan Latihan Profesi Guru, 1(2), pp.24-36.

[17] Afandi, M., 2014. Pentingnya penelitian tindakan kelas bagi guru dalam pembelajaran di sekolah dasar. Jurnal ilmiah pendidikan dasar, 1(1), pp.1-19.

[18] Akhyadi, A.S. and Mulyono, D., 2019. Program parenting dalam meningkatkan kualitas pendidikan keluarga. Abdimas Siliwangi, 1(1), pp.1-8. 